\title{
Short communication \\ Performance comparison of plant root biofilm, gravel attached biofilm and planktonic microbial populations, in phenol removal within a constructed wetland wastewater treatment system
}

\author{
Eyal Kurzbaum ${ }^{1 *}$, Felix Kirzhner ${ }^{2}$ and Robert Armon ${ }^{2}$ \\ 'Golan Research Institute, University of Haifa, P.O. Box 97, Katzrin 12900, Israel \\ ${ }^{2}$ Faculty of Civil \& Environmental Engineering, Division of Environmental, Water \& Agricultural Engineering, Technion-Israel Institute of Technology, \\ Haifa 32000 , Israel
}

\begin{abstract}
This study was performed in order to understand the relative contribution of a constructed wetland (CW) system's various components to phenol degradation $\left(100 \mathrm{mg} \cdot \mathrm{L}^{-1}\right)$ under controlled plant biomass/gravel/ water experimental ratios. This was done by division of a pilot-scale CW system into its components, with or without their associated bacteria: (i) gravel, plant and water; (ii) gravel and water; (iii) water; (iv) gravel; (v) plant; (vi) control (sterile water). The highest phenol biodegradation rate occurred for the gravel-attached biofilm followed by root-attached biofilm and planktonic population, which recorded a similar rate to each other and a much lower rate than the gravel-attached biofilm. A control containing CW planktonic inactivated bacteria (autoclaved water) did not impact phenol removal, revealing that microbial populations are the major factor in phenol removal. The differences in the phenol removal achieved could be attributed to higher numbers of specific phenol degraders on the gravel surface, compared to lower numbers of root-attached and planktonic bacterial fractions, as isolated using phenol-agar plates which contained phenol as the sole carbon source. The main contributor to our findings appears to be the larger surface area provided by the gravel bed compared to plant roots.
\end{abstract}

Keywords: biofilm; constructed wetland; gravel; microbial activity; phenol

\section{INTRODUCTION}

A constructed wetland $(\mathrm{CW})$ is an artificial marsh, created for anthropogenic discharge such as wastewater and stormwater runoff treatment. The $\mathrm{CW}$ concept offers high rates of organics, nutrients and solids removal, with relatively low construction, operation, and maintenance costs. It offers a cost-effective wastewater treatment alternative for small- to moderately-sized communities where suitable land is available. CWs are highly complex systems that remove contaminants by physical, chemical, and biological mechanisms that take place simultaneously or sequentially as the wastewater flows through the system (Kadlec and Knight, 1996).

The main biochemical transformations and nutrient consumption (mainly nitrogen and phosphorus) are achieved by the presence of plants and microorganisms. In subsurface flow CWs, a gravel bed (as porous support media) and vegetation provide surfaces upon which microorganisms can grow, sustained by the breakdown of organic materials. Microorganisms and natural physico-chemical processes are responsible for most organic pollutant removal and nitrogen transformation. These microorganisms are present in mainly two modes: planktonic (freely suspended in water) and attached. The attached form is either on the rhizoplane (root surface) or gravel support bed (Kadlec and Knight, 1996; Otte and Jacob, 2006).

Besides the abiotic surfaces which are colonized by various microorganisms, some researchers claim that CWs beneficial

\footnotetext{
* To whom all correspondence should be addressed.

๔ +97246608055; Fax: +97246961930; e-mail: ekurzbaum@univ.haifa.ac.il Received: 20 February 2015; accepted in revised form 26 November 2015
}

habitat is mainly provided by plant roots, due to the nature of their surface and exudates such as amino acids, simple sugars, complex carbohydrates and oxygen released close to the rootwater interface (Gersberg et al., 1986; Brix, 1997; Stottmeister et al., 2003). Nevertheless, there are no empirical data or models that accurately describe the impact of plant roots, in terms of their relative contribution to the water purification process, versus inert surfaces such as a gravel bed colonized or uncolonized by bacterial biofilm. Therefore, it is not clear whether the 'rhizosphere effect' significantly contributes to water treatment in CW systems; detailed insight into this aspect of CWs still needs to be developed. This study was designed to tackle this question by calculating the relative contribution of each system component (root, gravel and water), with or without their associated bacteria, to overall phenol removal. Phenol was chosen as it is a common pollutant and because extensive knowledge already exists on its biodegradation chemistry (Van Schie and Young, 2000).

The present study was focused on phenol degradation in a subsurface CW system (pilot scale) with emphasis on the relative contribution of the following components: plants, porous media, and microorganisms. The reduction of phenol in a CW system by biological and physico-chemical processes was measured through the biodegradation capability of roots and gravel-attached bacteria and their planktonic state.

\section{MATERIALS AND METHODS}

\section{Experimental set up}

Common reeds (Phragmites australis), gravel and water samples were taken from a 2-year-old subsurface flow CW mesocosm containing a limestone gravel bed, as already described 
in Zimmels et al. (2008). The system was fed with domestic sewage supplemented with phenol for 6 months prior to the study measurements. The water quality parameters of the CW feed water used are shown in Table 1. CW core samples were performed using a large metal core sampler $(15 \mathrm{~cm}$ internal diameter and $30 \mathrm{~cm}$ long). The sampled cores were as follows: 3 cores contained gravel + plants (each core contained 3 plants), 3 cores contained only plants ( 3 plants each), and 6 cores contained only gravel. Cores were taken from the upper section of the CW to obtain uniform core samples. Samples of gravel were taken from the upper part of the gravel column $(25 \mathrm{~cm})$, as more than $90 \%$ of organics biodegradation is attributed to the upper $10 \mathrm{~cm}$ of the porous bed in CW systems with vertical subsurface flow (Tietz et al., 2007). The samples were carefully transferred to $500 \mathrm{~mL}$ cylindrical beakers ensuring minimum damage to plant roots and to gravel-attached biofilm. Following transfer to beakers, CW water was added. Water samples were taken by using a sterile $100 \mathrm{~mL}$ glass pipette from $15 \mathrm{~cm}$ below the surface of the mesocosm's gravel bed. All treatments were fed with $100 \mathrm{~mL} \mathrm{CW}$ water, except two, to which sterile tap water was added. The sterile tap water supplemented experiments were performed in order to determine the extent of gravel-attached bacteria's role in phenol biodegradation excluded of CW planktonic bacteria (illustrated in Fig. 1), and as a sterile control (without any CW components). Each experimental beaker represents an area of $56.71 \mathrm{~cm}^{2}$ with depth of $5 \mathrm{~cm}$ of the sampled CW.
The amount of gravel in the gravel treatment beakers was $450 \pm 10 \mathrm{~g}$. Plant net biomass ( 3 plants) amounted to $50 \pm 5 \mathrm{~g}$ without the prerequisite to wash residual soil as their growth was completely hydroponic.

\begin{tabular}{|l|c|}
\hline \multicolumn{2}{|c|}{ TABLE 1 } \\
Water quality parameters of CW feed water used in the \\
present study
\end{tabular}

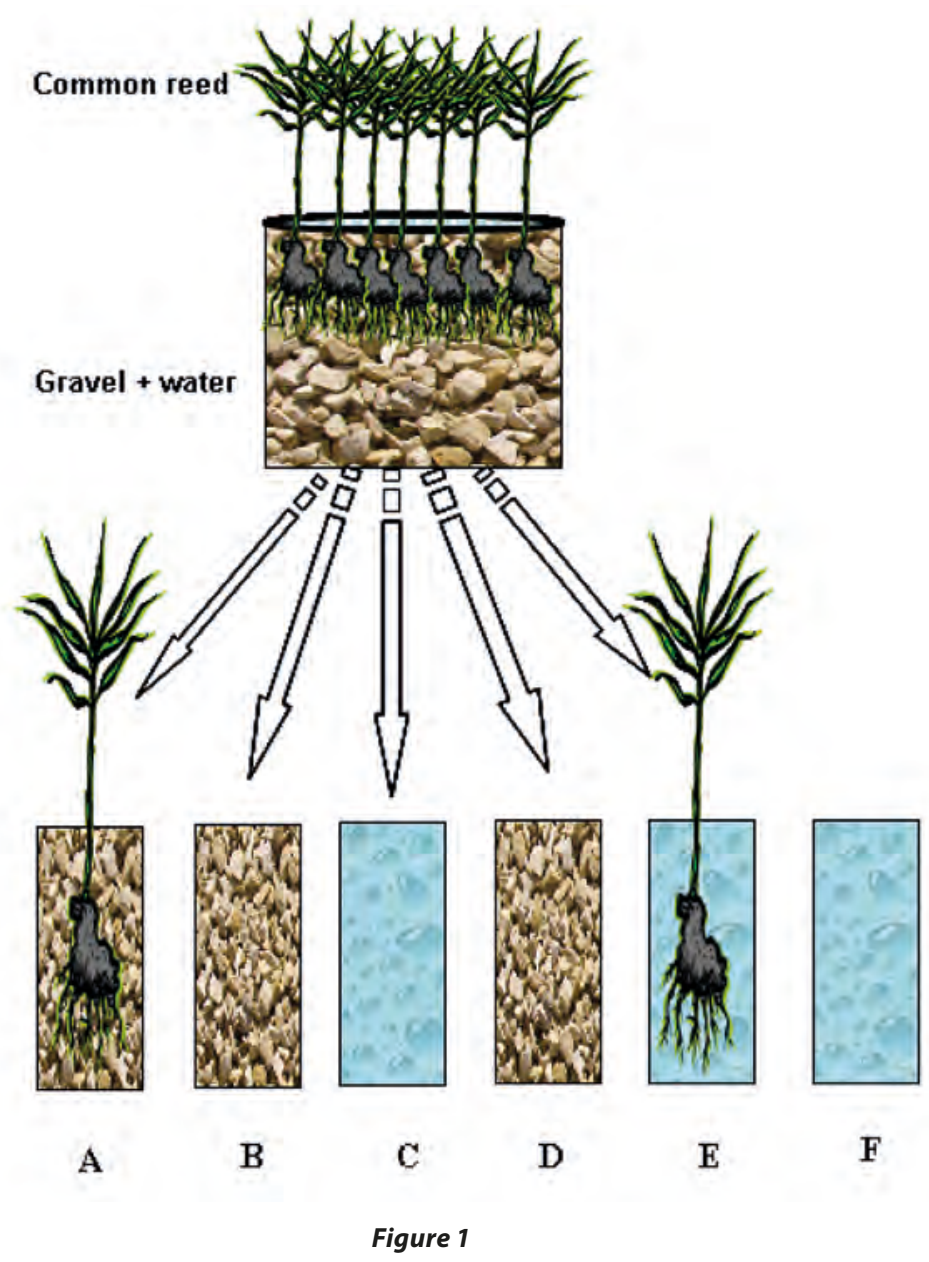

Schematic illustration of the different experimental constructed wetland system components transferred to cylindrical beakers. Letters represent the following treatments: (A) gravel, plant, water; (B) gravel, water; (C) water; (D) gravel; (E) plant; (F) control (sterile water) 
The different experimental set-ups contained the following components; consequently, each treatment contained different bacterial population fractions and densities:

- Treatment A was made up of 3 young plants with a total biomass of $50 \pm 5 \mathrm{~g}$ (including roots), $450 \pm 10 \mathrm{~g}$ gravel and $100 \mathrm{~mL} \mathrm{CW}$ water. This treatment was performed in order to discover the effect of plant, rhizospheric, gravel attached and planktonic microorganisms on phenol biodegradation.

- Treatment B was made up of $450 \pm 10$ g gravel and $100 \mathrm{~mL}$ $\mathrm{CW}$ water. This treatment was performed in order to discover the effect of gravel-attached and planktonic microorganisms on phenol biodegradation.

- Treatment $\mathrm{C}$ contained only CW water in order to estimate the contribution of planktonic bacteria to phenol biodegradation.

- Treatment D was made up of $450 \pm 10 \mathrm{~g}$ gravel and $100 \mathrm{~mL}$ sterile tap water. This treatment was performed in order to discover the effect of gravel-attached microorganisms on phenol biodegradation.

- Treatment $\mathrm{E}$ contained 3 young plants with a total biomass of $50 \pm 5 \mathrm{~g}$ (including roots) and $100 \mathrm{~mL}$ sterile tap water. This treatment was performed in order to discover the effect of plants and their associated (root biofilm) microorganisms on phenol biodegradation.

- Treatment F as a control contained sterile (autoclaved) $\mathrm{CW}$ water in order to exclude possible interaction between phenol and abiotic factors.

CW water added to each beaker was supplemented with phenol to reach an initial concentration of $100 \mathrm{mg} \cdot \mathrm{L}^{-1}$ for all set-ups. Each set-up was performed in triplicate. The different beakers were placed randomly on a rotary shaker (MRC, TS-400) and gently rotated $\left(20 \mathrm{r} \cdot \mathrm{min}^{-1}\right)$ to provide moderate mixing under 4 fluorescent lamps $\left(\sim 100 \mu \mathrm{mol}\right.$ photons $\left.\cdot \mathrm{m}^{-2} \cdot \mathrm{s}^{-1}\right)$ at $25 \pm 1^{\circ} \mathrm{C}$ (16-h light and 8-h dark condition) for $36 \mathrm{~h}$. Throughout the experiment, concentrations of phenol were monitored periodically (approx. every $5 \mathrm{~h}$ ) and bacterial population density was examined directly after the end of the experiment. Water $\mathrm{pH}$ was $7.5 \pm 0.2$ throughout the experiment in all treatments.

\section{Enumeration of total culturable heterotrophic and phenol-degrading bacteria}

Culturable heterotrophic bacteria enumeration in set-ups containing plants, gravel and CW water was performed as follows: plant stems were cut and the whole beaker volume was supplemented with 5 drops of sterile Tween 20, and sealed with several layers of parafilm (to prevent leakage). Each experimental beaker was vigorously shaken on a rotatory shaker (MRC, TS-400) at $250 \mathrm{r} \cdot \mathrm{min}^{-1}$ for $30 \mathrm{~min}$. Then the mixture was plated following serial dilutions in triplicate on nutrient agar (Difco, USA) and incubated for 6 days at $25 \pm 1^{\circ} \mathrm{C}$. Colony forming units (CFU) were counted and calculated as follows: $\left(\mathrm{CFU} \cdot \mathrm{mL}^{-1}\right) \times($ total volume of the experimental set-up). Rhizosphere and gravel-attached bacteria enumeration was performed by bacterial release as previously described by Garland (1996), with minor modifications. Phenol-degrading bacteria were enumerated using the same procedure, with the exception of the use of a solid minimal salts medium as the solid growth medium, supplemented with $50 \mathrm{mg} \cdot \mathrm{L}^{-1}$ phenol as a sole carbon and energy source (Kurzbaum et al., 2010).

\section{CW water parameters}

Water quality parameter measurement for CW feed water was performed according to Standard Methods (APHA, 1995). Phenol concentrations were measured using the 4 -aminoantipyrine colorimetric approach on supernatant of centrifuged samples (× $6000 \mathrm{~g}$ for $10 \mathrm{~min}$ ) (APHA, 1995).

\section{RESULTS AND DISCUSSION}

In order to define the specific contribution of each system component to phenol removal, the various components were tested separately (Fig. 2). Gravel-attached bacteria revealed the fastest removal kinetics for phenol (Treatment D) per volume of the tested system. The treatments which consisted of the planktonic population with or without root-attached population (Treatments A and B, respectively), as well as the gravel-attached population, did not increase overall phenol consumption.

There is strong evidence that gravel-attached bacterial populations played a major role in phenol removal in our pilot constructed wetland system. Phenol removal with the root-attached population alone and the planktonic bacterial population alone (Treatments $\mathrm{E}$ and $\mathrm{C}$, respectively) followed a similar kinetic pattern. The control (Treatment F) containing CW sterile water (inactivated bacteria) showed no impact on phenol concentration.

Calculation of phenol $_{50}$ from Fig. 2 revealed that Treatment A (gravel, plants and water) required $18 \mathrm{~h}$ to reduce the phenol concentration by half. Removal of the plant parameter (Treatment B) did not significantly change the time interval required for $50 \%$ phenol removal (17.5). Water alone, containing only planktonic bacteria (Treatment C) required a $29 \mathrm{~h}$ interval to reduce phenol concentration by half. By contrast, Treatment D (containing only gravel and active gravel-attached bacteria) removed $50 \%$ of the initial phenol concentration in $17 \mathrm{~h}$. Treatment E (only plants and their root-attached bacteria) gave a phenol ${ }_{50}$ of 29 , similar to Treatment $C$ (planktonic population) (Table 2).

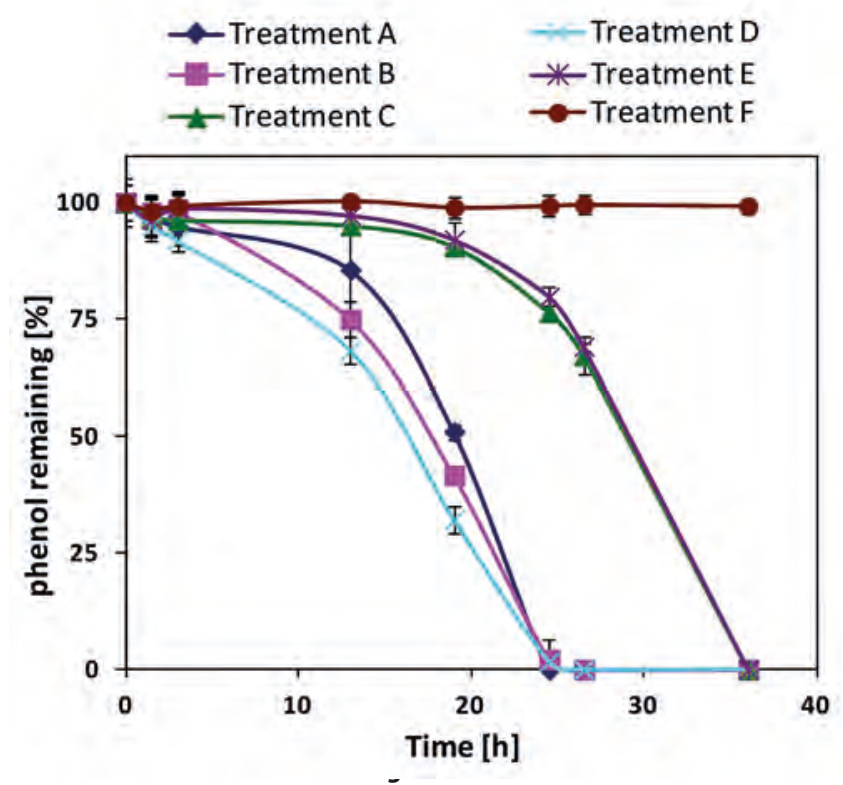

Percentage of phenol residual as a function of time. Different treatments containing various $C W$ combined components (comprising diverse bacterial population concentrations): (A) plants + gravel + water; (B) gravel + water; (C) water; (D) gravel + sterile water; (E) plants; (F) control (sterile $C W$ water). Data points represent average $\pm S . D ; n=3$. 


\begin{tabular}{|c|c|c|c|c|c|}
\hline \multicolumn{6}{|c|}{$\begin{array}{c}\text { TABLE } 2 \\
\begin{array}{c}\text { Enumeration of total culturable heterotrophic and phenol-degrading bacterial populations for different experimental } \\
\text { treatment set-ups }\end{array}\end{array}$} \\
\hline \multirow[b]{2}{*}{ Treatment } & \multirow[b]{2}{*}{$\begin{array}{l}\text { Bacterial population } \\
\text { positions }\end{array}$} & \multicolumn{4}{|c|}{ Number of total culturable and phenol-degrading bacteria (CFU/test system) ${ }^{a}$} \\
\hline & & $\begin{array}{c}\text { Total culturable } \\
\text { bacteria }\end{array}$ & $\begin{array}{c}\text { Phenol-degrading } \\
\text { bacteria }\end{array}$ & $\begin{array}{c}\% \text { of phenol } \\
\text { degraders from total } \\
\text { heterotrophs }\end{array}$ & $\begin{array}{l}\text { Phenol }_{50} \\
\text { (hour) }^{\mathrm{b}}\end{array}$ \\
\hline A & $\begin{array}{l}\text { Planktonic, gravel } \\
\text { attached, root attached }\end{array}$ & $3.32 \pm 2.4 \times 10^{10}$ & $1.60 \pm 1.2 \times 10^{10}$ & $48.02 \%$ & 18 \\
\hline B & $\begin{array}{l}\text { Planktonic, gravel } \\
\text { attached }\end{array}$ & $2.81 \pm 1.3 \times 10^{10}$ & $1.24 \pm 1.1 \times 10^{10}$ & $44.13 \%$ & 17.5 \\
\hline C & Planktonic & $4.13 \pm 2.8 \times 10^{9}$ & $2.86 \pm 2.1 \times 10^{9}$ & $69.27 \%$ & 29 \\
\hline D & Gravel attached & $2.40 \pm 2.7 \times 10^{10}$ & $9.56 \pm 3.7 \times 10^{9}$ & $39.81 \%$ & 17 \\
\hline $\mathbf{E}$ & Root attached & $5.12 \pm 2.9 \times 10^{9}$ & $3.55 \pm 2.7 \times 10^{9}$ & $69.35 \%$ & 29 \\
\hline$F$ & Control (sterile) & 0 & 0 & - & $\infty^{b}$ \\
\hline
\end{tabular}

a The experimental set-ups volume was $100 \mathrm{~mL}$.

b Time required to remove $50 \%$ of the initial phenol concentration.

The contribution to phenol removal by the treatments with plants could also be attributed to direct adsorption and absorption by the plant tissues (Tsao, 2003). However, this aspect was not analysed further in this study. The control (Treatment F) containing inactivated CW planktonic bacteria (autoclaved water) did not impact phenol removal at all, therefore revealing that microbial populations are the major factor bringing about phenol removal in CWs.

These findings are supported by the enumeration of total culturable heterotrophic and phenol-degrading bacterial populations for the various treatments (A to F) (Table 2). The results show that the highest bacterial concentration was found in the gravel-attached fraction (a fact that led to faster phenol consumption in these treatments). In all treatments phenol degraders made up between $39 \%$ and $69 \%$ of the total culturable heterotrophic population.

According to the results, gravel-attached bacteria made the most significant contribution to total phenol reduction, while root-attached and planktonic bacteria made a minor contribution with a much slower phenol degradation rate. These differences could be attributed to higher numbers of specific phenol degraders on the gravel surface, compared to lower numbers of root-attached and planktonic bacterial fractions.

As the present $\mathrm{CW}$ is an open-circulating system, phenol evaporation or adsorption onto its components (gravel limestone bed, bacterial biomass, plant biomass) should be taken in account when measuring phenol removal. According to preliminary experiments, phenol evaporation/adsorption to the system's components was found to be negligible. However, our studies revealed that having sterile plants (deprived of rhizospheric bacterial activity: precluded by antibiotic supplementation) as additional biomass present in the system resulted in $\sim 10 \%$ phenol removal (over 35 h) (Kurzbaum et al., 2014). Phenol reduction due to the presence of plants has already been described in previous studies, with various reduction rates reported (Cunningham et al., 1996), and using different plants, such as willow trees (Ucisik and Trapp, 2006), soybean plants (McFarlane et al., 1987) and alfalfa plants (Flocco et al., 2002). However, in these studies sterility was not always declared, thus the contribution of solely the plant in many of these studies is unclear.
The ammonia concentration in the feed wastewater was $51 \mathrm{mg} \cdot \mathrm{L}^{-1}$. In our batch treatments, the hydraulic retention time (HRT) was short (24-36 h) compared to common HRTs in efficient CW systems (several days). Therefore, it can be assumed that ammonia removal, if it occurred, did not affect phenol consumption rates, as was also shown in a previous study by Tee et al. (2009). Nevertheless, in large CW systems nitrification may play a key role in dissolved oxygen consumption and therefore may reduce the degradation rate of phenols and other organics in the treated water.

Biofilm accumulation on solid surfaces provides a preferable environment for bacteria, as has already been pointed out by other authors (Van Loosdrecht et al., 1990). It is likely that in the present study the higher bacterial numbers on gravel surfaces (in the actual experimental volume) can be related to the higher surface area of the gravel compared to plant roots (the actual surface area of the two experimental components cannot be compared). Moreover, it is suggested that as high concentrations of organics were present in the treated water $\left(435 \mathrm{mg} \cdot \mathrm{L}^{-1} \mathrm{COD}\right)$, the root and gravel surfaces served merely as attachment surfaces, and the claim that plants, by rhizodeposition and oxygen release, serve as a more hospitable environment than gravel (Tanner, 2001; Stottmeister et al., 2003), was not realised in this study (due to the apparently lower surface area).

\section{CONCLUSIONS}

In conclusion, from our study of the contribution of each CW component's associated bacterial population to phenol degradation, the gravel bed was the main contributor, followed by an equal contribution of plant roots and water (planktonic population) (for a specific system volume). It is likely that the main reason for this finding is the larger surface area provided by the gravel bed compared to roots and the fact that there was high organic content in the treated water. A future study should be focused on the contribution of each component in a CW system to the overall degradation of water contaminants in a large-scale and mature CW system (i.e., more than 4 years of operation). 


\section{REFERENCES}

APHA (1995) Standard Methods for the Examination of Water and Wastewater (16 ${ }^{\text {th }}$ edn). American Public Health Association/ American Water Works Association/ Water Environment Federation, Washington DC, USA.

BRIX H (1997) Do macrophytes play a role in constructed treatment wetland? Water Sci. Technol. 35 11-17. http://dx.doi.org/10.1016/ S0273-1223(97)00047-4

CUNNINGHAM SD, ANDERSON TA, SCHWAB AP and HSU FC (1996) Phytoremediation of soils contaminated with organic pollutants of outstanding interest. Adv. Agron. 56 55-114. http://dx.doi. org/10.1016/S0065-2113(08)60179-0

FLOCCO CG, LO BALBO A, CARRANZA MP and GIULIETTI AM (2002) Removal of phenol by alfalfa plants (Medicago sativa L.) grown in hydroponics and its effect on some physiological parameters. Acta Biotechnol. 22 43-54. http://dx.doi org/10.1002/1521-3846(200205)22:1/2<43::AID-ABIO43>3.0.CO;2-3

GARLAND JL (1996) Analytical approaches to the characterization of samples of microbial communities using patterns of potential C source utilization. Soil Biol. Biochem. 28 213-221. http://dx.doi. org/10.1016/0038-0717(95)00112-3

GERSBERG RM, EIKINS BV, LYON SR and GOLDMAN CR (1986) Role of aquatic plants in wastewater treatment by artificial wetlands. Water Res. 20 363-368. http://dx.doi. org/10.1016/0043-1354(86)90085-0

KADLEC R and KNIGHT R (1996) Treatment Wetlands. Lewis Publishers, Chelsea, MI, USA.

KURZBAUM E, KIRZHNER F and ARMON R (2014) A hydroponic system for growing gnotobiotic vs. sterile plants to study phytoremediation processes. Int. J. Phytoremediation 16 267-274. http:// dx.doi.org/10.1080/15226514.2013.773278

KURZBAUM E, KIRZHNER F, SELA S, ZIMMELS Y and ARMON R (2010) Efficiency of phenol biodegradation by planktonic Pseudomonas pseudoalcaligenes (a constructed wetland isolate) vs. root and gravel biofilm. Water Res. 44 5021-5031. http://dx.doi. org/10.1016/j.watres.2010.07.020

MCFARLANE JC, PFLEEGER T and FLETCHER J (1987)

Transpiration effect on the uptake and distribution of bromacil, nitrobenzene, and phenol in Soybean plants. J. Environ. Qual. 16 372-376. http://dx.doi.org/10.2134/ jeq1987.00472425001600040014x

OTTE ML and JACOB DL (2006) Constructed wetlands for phytoremediation: rhizofiltration, phytostabilisation and phytoextraction pp. 57-67. In: Mackova M, Dowling DN and Macek $\mathrm{T}$ (eds) Phytoremediation and Rizhoremediation. Springer, The Netherlands. http://dx.doi.org/10.1007/978-1-4020-4999-4

STOTTMEISTER U, WIESNER A, KUSCHK P, KAPPELMEYER M and KASTER M (2003) Effects of plants and microorganisms in constructed wetlands for wastewater treatment. Biotechnol. Adv. 22 93-117. http://dx.doi.org/10.1016/j.biotechadv.2003.08.010

TANNER CC (2001) Plants as ecosystems engineers in subsurface-flow treatment wetlands. Water Sci. Technol. 44 9-17.

TEE HC, SENG CE, NOOR AM, LIM PE (2009) Performance comparison of constructed wetlands with gravel-and rice husk-based media for phenol and nitrogen removal. Sci Total Environ. 407 3563-3571. http://dx.doi.org/10.1016/j.scitotenv.2009.02.017

TIETZ A, KIRSCHNER A, LANGERGRABER G, SLEYTR K, and HABERL R (2007) Characterisation of microbial biocoenosis in vertical subsurface flow constructed wetlands. Sci. Total Environ. 380 163-172. http://dx.doi.org/10.1016/j.scitotenv.2006.11.034

TSAO DT (2003) Phytoremediation: Advances in Biochemical Engineering/Biotechnology. Springer, Berlin. http://dx.doi. org/10.1007/3-540-45991-X

UCISIK AS and TRAPP S (2006) Uptake, removal, accumulation, and phytotoxicity of phenol in willow trees (Salix viminalis). Environ. Toxicol. Chem. 25 2455-2460. http://dx.doi.org/10.1897/05-457R.1

VAN LOOSDRECHT MCM, LYKLEMA J, NORDE W and ZEHNDER AJB (1990) Influence of interfaces on microbial activity. Microbiol. Rev. 54 75-87.

VAN SCHIE PM, YOUNG LY (2000) Biodegradation of phenol: mechanisms and applications. Bioremediat. J. 4 1-18. http://dx.doi. org/10.1080/10588330008951128

ZIMMELS Y, KIRZHNER F and SCHREIBER J (2008) Removal of high organic loads from winery wastewater by aquatic plants. Water Environ. Res. 80 806-822. http://dx.doi. org/10.2175/106143008X296460 